\title{
Essential oils of Tahiti lemon and cinnamon bark in control of storage fungi and the physiological and sanitary quality of beans
}

\author{
Óleos essenciais de limão Taiti e canela em casca no controle de \\ fungos de armazenamento e na qualidade fisiológica e sanitária de feijão
}

\author{
Renan Paganini Valentini' (D), Lisandro Tomas da Silva Bonome' (D), Gabriela Silva Moura1* (D), \\ Diogo José Siqueira' ${ }^{1}$, Yasmin Tomazi' ${ }^{1}$; Gilmar Franzener ${ }^{1}$ (D), \\ Henrique von Hertwig Bittencourt ${ }^{1}$ if
}

\begin{abstract}
With the objective to evaluate the efficiency of essential oils of Citrus latifolia (Tahiti lemon) and Cinnamomum zeylanicum (cinnamon bark) in the control of plant pathogens Penicillium sp. and Aspergillus sp. and the quality of the bean seeds, two experiments were conducted. In the first one, the effect of essential oils of C. latifolia and C. zeylanicum was evaluated in vitro development of the fungi Penicillium sp. and Aspergillus sp. and, in the second one, the influence of essential oils on the physiological and sanitary quality of bean seeds. The variables mycelial growth, conidial germination and sporulation of Penicillium sp. and Aspergillus sp. were measured in the first experiment, while the seed germination test, first count of germination, germination speed index (GSI) and sanity test of bean seeds were measured in the second. The essential oil (EO) of C. zeylanicum was more efficient than C. latifolia in the control of Aspergillus sp. and Penicillium sp., but decreased the physiological quality of the beans seeds. The fungal diversity identified in the seed health test was composed by fungi of the genera Aspergillus, Penicillium, Cladosporium, Fusarium, Chaetomium and Rhizopus. The results indicate the potential of the use of these EOs in the seeds treatment.
\end{abstract}

KEYWORDS: Phaseolus vulgaris; Penicillium sp.; Aspergillus sp.; Cinnamomum zeylanicum; Citrus latifolia.
RESUMO: Com o objetivo de avaliar a eficiência dos óleos essenciais de Citrus latifolia (limão taiti) e Cinnamomum zeylanicum (canela em casca) no controle dos fitopatógenos Penicillium sp. e Aspergillus sp. e na qualidade das sementes de feijão, foram conduzidos dois experimentos. No primeiro, avaliou-se o efeito dos óleos essenciais de C. latifolia e C. zeylanicum no desenvolvimento in vitro dos fungos Penicillium sp. e Aspergillus sp. e, no segundo, a influência dos óleos essenciais sobre a qualidade fisiológica e sanitária das sementes de feijão. As variáveis crescimento micelial, germinação de conídios e esporulação de Penicillium sp. e Aspergillus sp. foram aferidas no primeiro experimento, enquanto o teste de germinação de sementes, primeira contagem de germinação, índice de velocidade de germinação (IVG) e teste de sanidade de sementes de feijão foram aferidas no segundo. O óleo essencial (OE) de $C$. zeylanicum foi mais eficiente que $C$. latifolia no controle dos fungos Aspergillus sp. e Penicillium sp., mas diminuiu a qualidade fisiológica das sementes de feijão. A diversidade fúngica identificada no teste de sanidade de sementes foi composta por fungos dos gêneros Aspergillus, Penicillium, Cladosporium, Fusarium, Chaetomium e Rhizopus. Os resultados indicam o potencial do uso desses óleos essenciais no tratamento de sementes.

PALAVRAS-CHAVE: Phaseolus vulgaris; Penicillium sp.; Aspergillus sp.; Cinnamomum zeylanicum; Citrus latifolia. 


\section{INTRODUCTION}

The common bean (Phaseolus vulgaris L.) stands out among the agricultural crops in Brazil as a result of the extension of cultivated area, production value and importance as a source of protein for the population (TOLEDO et al., 2009). Bean is cultivated by approximately 2 million Brazilian farmers, being small farmers responsible for $64 \%$ of production in areas smaller than 5 hectares (STONE et al., 2013).

The contamination of the beans by fungi after harvesting can determine significant losses during the storage period, compromising the grains quality and the germination and vigor of the seeds (SILVA et al., 2013). In addition to direct damage to the grains and seeds, they may introduce pathogens into new areas or even introduce a race of a pathogen that may cause major damage to the culture (DALLA PRIA; SILVA, 2010; MENTEN, 1995). Thus, the treatment of the seeds constitutes an important method for preserving its original characteristics and for the prevention of contamination of areas free of pathogens spread by seeds.

Penicillium and Aspergillus genera are among the most important for stored bean grains and seeds (MARINO; MESQUITA, 2009). The use of fungicides applied in various formulations and dosages, has been the most usual and effective for the treatment of the seeds (VANZOLINI et al., 2000). However, the use of synthetic products causes adverse effects to the environment and human health (GHINI; KIMATI, 2000), arousing interest in the use of alternative methods with natural products for treatment of the seeds, in the form of extracts, powders and essential oils (EOs).

The EOs represent an important alternative to be exploited in the treatment of the seeds, because in addition to the fungicide effect they are normally biodegradable and have low toxicity to humans and animals (KRISCH et al., 2011; SIVAKUMAR; BAUTISTA-BAÑOS, 2014). Several EOs have been showing promising results for the treatment of the seeds, as the oils of Allium sativum L. and Cinnamomum zeylanicum in control of the fungus Aspergillus flavus (VIEGAS et al., 2005a), Citrus latifolia in the inhibition of conidial germination of Penicillium digitatum and $P$. italicum (FRENCH et al., 1978), Moringa oleifera on the mycelial growth of Fusarium oxysporum, Cladosporim Sphaerospermum and Colletotrichum lindemuthianum (SILVA et al., 2009).

In addition to efficiency in the microorganisms control, it is important that compounds present in the $\mathrm{EO}$ do not affect the seeds physiological quality. GOMES et al. (2016) found that clove oil in India at a concentration of $2 \mathrm{~mL} . \mathrm{L}^{-1}$ reduced the physiological quality of lima bean seeds (Phaseolus lunatus L.). Similar results were observed by VIEGAS et al. (2005b) in which the oil of garlic (Allium sativum L.) and cinnamon (Cinnamomun Zeylanicum Breyn.) reduced the germination of peanut seeds (Arachis hypogaea L.).
Hypothetizing the potential use of EOs in the control of seed phytopathogenic fungi, the objective of this study was to evaluate the efficiency of EOs of Citrus latifolia and Cinnamomum zeylanicum in storage control of fungi Penicillium sp. and Aspergillus sp. in beans and their influence on the physiological quality of the seeds.

\section{MATERIALS AND METHODS}

The experiments were conducted in the Laboratories of Pathology and Germination and Plant Growth of the Universidade Federal da Fronteira Sul (UFFS), Laranjeiras do Sul, Paraná.

\section{Obtainment of phytopathogenic fungi, essential oils and bean seeds}

The fungi Penicillium sp. and Aspergillus sp. were isolated from common bean seeds variety Tuiuiú using the seed health test, incubation on paper substrate by the blotter test method (BRASIL, 2009). A single conidium was collected and cultivated in potato-dextrose-agar (PDA) and kept at $25 \pm 2^{\circ} \mathrm{C}$, being used with 10 days of growth. Whereas the EOs of Citrus latifolia and Cinnamomum zeylanicum, were purchased from Quinarí Casa das Essências, and the bean seed variety Tuiuiú purchased from rural producers in the municipality of Laranjeiras, Paraná.

Two experiments were conducted to achieve the work objectives. In the first experiment, the effect of EOs of $C$. latifolia and C. zeylanicum was evaluated in vitro development of the fungi Penicillium sp. and Aspergillus sp., and, in the second one, the influence of EOs on the physiological and sanitary quality of bean seeds.

\section{Effect of essential oils in the development of Penicillium sp. and Aspergillus sp.}

The experimental design was completely randomized with ten treatments and four replications. For each one of them was used EO of Citrus lafifolia and Cinnamomum zeylanicum concentrations of 0.1; $0.2 ; 0.4$ and $0.8 \%$, fungicide and control, for the fungi Penicillium sp. and Aspergillussp. The culture medium in PDA was sterilized at a temperature of $121^{\circ} \mathrm{C}$ for 20 minutes. After reaching a temperature of approximately $40^{\circ} \mathrm{C}$ the aliquots of $0.1 ; 0.2 ; 0.4$ and $0.8 \%$ of EOs of C. latifolia and C. zeylanicum were added.

The same procedure was performed for the addition of the aliquot in the proportion of $2.5 \%$ of the fungicide $\left(150 \mathrm{~g} \mathrm{~L}^{-1}\right.$ carbendazim + thiram $\left.350 \mathrm{~g} \mathrm{~L}^{-1}\right)$ in PDA medium. The solutions PDA / EO and the PDA / fungicide were poured on Petri plates and it took 2 hours for the solidification of the medium. The growing medium for the control treatment counted only with PDA. 
Portions of approximately $10 \mathrm{~mm}$ in diameter, containing the mycelium of fungi Penicillium sp. and Aspergillus sp., were deposited in the center of the Petri plates. The plates were sealed with plastic film and incubated at $25 \pm 2^{\circ} \mathrm{C}$ for seven days. After this period, the following variables were measured: mycelial growth, conidial number formed and germinated.

The measurement of the diameters $(\mathrm{cm})$ horizontal and vertical position of each colony was performed with the aid of a ruler by determining the average of the two values to infer the mycelial growth medium of the colony. Then, a count of the number of developed conidia was performed. Therefore, $10 \mathrm{~mL}$ of distilled water were added in the Petri dish, and the scraping of the colony with spatula was performed. The volume from adding water and scraping of the colony was filtered in two layers of gauze. After filtration, dilution of the suspension was performed, adding more $40 \mathrm{~mL}$ of distilled water, originating the suspension of $50 \mathrm{~mL}$. In the suspension, the count of the number of conidia with a Neubauer chamber was carried out, with the aid of an optical microscope. A count of the number of conidia was held seven days after the beginning of the experiment.

For counting the number of germinated conidia, microscopy slides with a layer of agar were placed in Petri plates lined with moistened filter paper. After the agar solidification, it was deposited on each end of the slide $30 \mu \mathrm{L}$ of the conidial suspension of the fungi Penicillium sp. and Aspergillus sp., in the concentration of $2 \times 10^{5}$ conidia $\mathrm{mL}^{-1}$. This concentration was determined by counting the conidia in a Neubauer chamber, so that 20 conidia were present in the central quadrant of the chamber. At the ends of the slide, it was also been added $30 \mu \mathrm{L}$ of the respective treatments. In the control treatment, only the aliquot containing the conidia on the agar was added. The plates were incubated for 24 hours in the dark, being performed the paralysis of the conidia development by adding $10 \mu \mathrm{L}$ of cotton blue on each point that contained the conidia on the slides after this period.

For the counting of germinated conidia, the slides were observed under an optical microscope. The count of 50 conidia was performed randomly in each plot for determination of the percentage of germinated conidia, being considered as germinated conidia the ones whose emitted germ tubes are greater than or equal to the smallest diameter of conidium.

The data were subjected to analysis of variance, being applied regression analysis or multiple comparison of means by Tukey test $(\mathrm{p}<0.05)$, as appropriate.

\section{Influence of treatments with essential oils of $C$. Iatifolia and C. zeylanicum on the physiological quality of beans seeds}

For the germination tests and first count of germination, a completely randomized experimental design was used, in factorial scheme $2 \times 9$, being both fungi (Penicillium sp. and Aspergillus sp.) and nine treatments, being EO of $C$. latifolia at concentrations of 0.4 and $0.8 \%$ and $C$. zeylanicum at concentrations of $0.1 ; 0.2 ; 0.4$ and $0.8 \%$, control, positive control and negative control. For the GSI, the experimental design completely randomized was used, in factorial scheme $2 \times 8$, being both fungi (Penicillium sp. and Aspergillus sp.) and eight treatments, being EO of C. latifolia at concentrations of 0.4 and $0.8 \%$ and $C$. zeylanicum at concentrations of $0.1 ; 0.2 ; 0.4$ and $0.8 \%$, control, positive control and negative control. For the seed health test, it was used a completely randomized experimental design with eight treatments, being $\mathrm{EO}$ of $C$. latifolia at concentrations of 0.4 and $0.8 \%$ and C. zeylanicum at concentrations of $0.1 ; 0.2 ; 0.4$ and $0.8 \%$, positive control and negative control, for seeds inoculated with the fungi Penicillium sp. and Aspergillus sp. All tests were performed with four replicates per treatment.

The seeds were distributed in two plastic bags, and the inoculation of one of the portions was performed with the fungus Penicillium sp., and the other with the fungus Aspergillus sp. For the inoculation, $2 \mathrm{~mL}$ of suspension containing distilled water at a concentration of $2 \times 10^{5}$ conidia $\mathrm{mL}^{-1}$, of the respective fungus in each plastic bag, and later the homogenization was performed by shaking the plastic bags. After being inoculated, the seeds remained exposed on the laboratory bench in the shade for approximately 4 hours, so that they were not wet.

After completing the inoculation, the seeds were treated with EOs of $C$. latifolia at concentrations of 0.4 and $0.8 \%$ and $C$. zeylanicum at concentrations of $0.1 ; 0.2 ; 0.4$ and $0.8 \%$. It was chosen to use only the highest concentrations of the EO of C. latifolia, because the two lowest concentrations did not differ from the control in the previous experiment. The positive control was treated with fungicide and the negative control was composed by seeds inoculated with the fungi Penicillium sp. and Aspergillus sp. and not treated with EOs. It was also used an additional control composed by non-inoculated and not treated seeds. In the case of treatment of positive control, the determination of carbendazim fungicide was carried out $\left(150 \mathrm{~g} \mathrm{~L}^{-1}+\right.$ thiram $\left.350 \mathrm{~g} \mathrm{~L}^{-1}\right)$ at a dose of $300 \mathrm{~mL} .100 \mathrm{~kg}^{-1}$ of seed, plus the same volume in water. The seeds of each treatment were separated into individual plastic bags, and in each one of them, aliquots of the respective EOs and the same volume of water were added. For the negative control and additional control, it was used only the volume of water corresponding to twice the volume of fungicide used. After performing the treatments, the plastic bags were stirred for homogenization and the seeds moved to Kraft paper bags, being incubated for 14 days in the dark at approximately $20^{\circ} \mathrm{C}$. The treatment of the seeds was performed 24 hours after inoculation of seeds with Penicillium sp. and Aspergillus sp. 


\section{Germination test and first count of germination}

Four replications of 50 seeds for each treatment were used, arranged in rolls of paper moistened with distilled water in a proportion of 2.5 times the weight of the dry paper, which were kept in a germinator Mangelsdorf type, at a temperature of $25^{\circ} \mathrm{C}$ with constant light. The evaluations were performed at $5^{\text {th }}$ and $9^{\text {th }}$ day counting the normal, abnormal, dead and dormant seedlings, and the results were expressed in percentage (BRASIL, 2009).

\section{Germination speed index}

The test was conducted in conjunction with the germination test, performing the daily evaluation of seedlings from the moment in which the first normal seedling appeared, which were computed and withdrawn from the substrate each day. This evaluation was extended to the $9^{\text {th }}$ day after the assembly of the experiment, allowing to determine the GSI (MAGUIRE, 1962) (Equation 1).

$\mathrm{GSI}=\mathrm{N} 1 / \mathrm{D} 1+\mathrm{N} 2 / \mathrm{D} 2+\ldots .+\mathrm{Nn} / \mathrm{Dn}$

Being GSI the germination speed index, Nn the number of seedlings germinated on the nth day after sowing, and Dn the nth day after implanting the test.

\section{Seed health testing}

Four replications of 25 seeds were used for each treatment, and the seeds placed in gearbox type boxes, disinfested with alcohol $70 \%$ and lined with two sheets of filter paper moistened with 2.5 times the volume of their weight in water. Then, the boxes were sealed with plastic film and placed in $\mathrm{BOD}$ at $25^{\circ} \mathrm{C}$ and without photoperiod, for 24 hours. Afterwards, they were placed at a temperature of $-20^{\circ} \mathrm{C}$ for 24 hours, and then returned to BOD at $25^{\circ} \mathrm{C}$ for five days, when the pathogens present in the seeds were identified. The seeds used in the sanity test, received the same treatments as those used in the germination test. In light of this, it is supposed that the presence of the fungi Aspergillus sp. and Penicillium sp. in seeds inoculated with the fungus Aspergillus sp. and Penicillium sp., respectively, are supposed to be from the same inoculation, and not from the natural flora present in the seeds.

\section{RESULTS AND DISCUSSION}

The EOs of C. latifolia and C. zeylanicum influenced the mycelial growth of both Penicillium sp. and Aspergillus sp. The mycelial growth of Penicillium sp. was reduced with the increase in the concentration of $C$. latifolia, differing $0.4 \%$ from the control (Table 1), whereas the EO of C. zeylanicum completely inhibited the mycelial growth in all the concentrations used. These results show the potential fungicidal activity of EO of C. zeylanicum, which was as efficient as the fungicide in the control of the mycelial growth of the fungus Penicillium sp.

The use of EO of $C$. latifolia caused reduction in the sporulation of Penicillium sp. in all the concentrations used, except for the concentration of $0.2 \%$, which did not differ from the control; whereas the EO of C. zeylanicum, promoted the complete inhibition of sporulation of Penicillium sp. in all the concentrations. The EOs have different secondary metabolites, presenting biological activities that can be elicitor or antimicrobial (CUNHA et al., 2015; OOTANI et al., 2013; SILVA et al., 2014). OOTANI et al. (2016) also observed

Table 1. Mycelial growth, sporulation and conidial germination of Penicillium sp. in potato-dextrose-agar culture medium with different concentrations of essential oils of Citrus latifolia and Cinnamomum zeylanicum.

\begin{tabular}{|c|c|c|c|}
\hline Treatments & $\begin{array}{c}\text { Mycelial' }^{1} \\
\text { growth }(\mathrm{cm})\end{array}$ & $\begin{array}{l}\text { Sporulation }{ }^{2} \text { (number of } \\
\left.\text { conidia/colony } 10^{7}\right)^{*}\end{array}$ & Germination (\%)* \\
\hline Control & $2.63 \mathrm{~d}$ & $17.50 \mathrm{~d}$ & $38.00 \mathrm{~d}$ \\
\hline Fungicide & $0.00 \mathrm{a}$ & $0.00 \mathrm{a}$ & $14.00 \mathrm{c}$ \\
\hline EO C. Iatifolia $0,1 \%$ & $2.61 \mathrm{~cd}$ & $8.43 c$ & $51.00 \mathrm{~d}$ \\
\hline EO C. Iatifolia $0,2 \%$ & $2.65 \mathrm{~d}$ & $18.75 \mathrm{~d}$ & $50 \mathrm{~d}$ \\
\hline EO C. Iatifolia $0,4 \%$ & $2.17 \mathrm{c}$ & $9.37 \mathrm{c}$ & $44.50 \mathrm{~d}$ \\
\hline EO C. Iatifolia ০,8\% & $1.66 \mathrm{~b}$ & $3.95 b$ & $40.65 d$ \\
\hline EO C. zeylanicum $0,1 \%$ & $0.00 \mathrm{a}$ & $0.00 \mathrm{a}$ & $4.50 \mathrm{~b}$ \\
\hline EO C. zeylanicum 0,2\% & $0.00 \mathrm{a}$ & $0.00 \mathrm{a}$ & $1.50 \mathrm{ab}$ \\
\hline EO C. zeylanicum $0,4 \%$ & $0.00 \mathrm{a}$ & $0.00 \mathrm{a}$ & $0.50 \mathrm{ab}$ \\
\hline EO C. zeylanicum 0,8\% & $0.00 \mathrm{a}$ & $0.00 \mathrm{a}$ & $0.00 \mathrm{a}$ \\
\hline
\end{tabular}

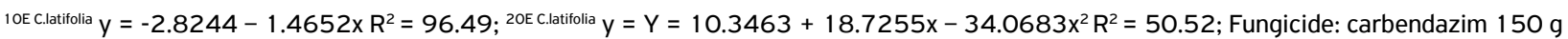
$\mathrm{L}^{-1}+$ thiram $350 \mathrm{~g} \mathrm{~L}^{-1}$; means followed by the same letter in column do not differ statistically among themselves by Tukey test $(p<0.05)$; ${ }^{*}$ for the purpose of analysis, the data were transformed to square root of $Y+1.0-$ Sqrt $(Y+1.0)$; EO: essential oils. 
total inhibition of fungal development in seeds of cowpea (Vigna unguiculata (L.) Walp.) stored when treated with EO of Cymbopogon nardus L., being indicated as a potential alternative in the seed treatment in the concentration starting from $10 \%$.

The $\mathrm{EO}$ of $C$. latifolia was not effective in the reduction of the conidial germination of Penicillium sp., however, the $\mathrm{EO}$ of C. zeylanicum decreased this parameter in proportion to the concentration of oil until it reached $100 \%$ control at a concentration of $0.8 \%$ (Table 1). CHAGAS et al. (2014), in a study on the influence of fungicides, EOs and biological agents to control Amphobotrys ricini in castor bean plant, also verified total control in the mycelial growth with application of $\mathrm{EO}$ of C. zeylanicum at a concentration of $0.3 \%$.

The EO of C. zeylanicum showed similar results to those observed with the fungicide in three parameters, being thus a potential natural fungicide, completely inhibiting the mycelial growth and sporulation of the fungus Penicillium sp.

According to MARJANLO et al. (2009), among the several alternatives, EOs have called the attention of researchers, for their potential in protection of plants. Among the EOs, C. zeylanicum has been explored by presenting biological activities, such as antifungal effect (BITU et al., 2016) and antibacterial (AL-BAYATI; MOHAMMED, 2009).

As observed for the fungus Penicillium sp. (Table 1), the $\mathrm{EO}$ of $C$. latifolia promoted reduction in the mycelial growth of Aspergillus sp. To the extent of increasing the concentration of the latter, given that only the $0.1 \%$ concentration did not differ from the control. The EO of C. zeylanicum also promoted total inhibition in the mycelial growth of Aspergillus sp. in all the concentrations used (Table 2).

No concentration of the EO of $C$. latifolia was efficient to reduce the sporulation of Aspergillus sp. (Table 2). In contrast, the $\mathrm{EO}$ of $C$. zeylanicum proved to be efficient, completely inhibiting the mycelial growth and sporulation of Aspergillus sp., in all concentrations. The conidial germination of Aspergillus sp. was reduced in all concentrations of C. zeylanicum and at a concentration of $0.8 \%$ of C. latifolia (Table 2). It should be emphasized that, in low concentrations, 0.2 and $0.4 \%$ of $C$. zeylanicum was capable of promoting complete inhibition on germination of conidia of Aspergillus sp.

The EOs represent an important alternative for treatment of seeds, because in addition to the fungicide effect (KRISCH et al., 2011) they are normally biodegradable and have low toxicity to humans and animals (KRISCH et al., 2011, SIVAKUMAR; BAUTISTA-BAÑOS, 2014). Checking the efficiency of EOs in sanitary and physiological quality in lima beans seeds (Phaseolus lunatus L.), the EO of basil was also able to promote the reduction in the development of Aspergillus sp. at a concentration of $0.1 \%$ (GOMES et al., 2016).

Regarding the treatment with fungicide (Table 2), it was noted a reduction in mycelial growth, sporulation and also on conidia germination of Aspergillus sp., however, there was no full control as observed in the mycelial growth and sporulation of Penicillium sp. (Table 1).

In view of the potential that the seeds have in the spread of diseases and chemical treatments that are performed for the control of these pathogens, the use of EOs of $C$. latifolia and C. zeylanicum may represent an alternative method for controlling phytopathogenic fungi in stored seeds. The results presented in this study demonstrate the greatest potential of fungicidal activity of $\mathrm{EO}$ of C. zeylanicum, which was able to completely inhibit the mycelial growth and sporulation of Penicillium sp. and Aspergillus sp.

The inoculation of the common bean seeds with the fungi Aspergillus sp. and Penicillium sp., drastically reduced the seeds germination in 31 and $41.5 \%$, respectively, compared to the uninoculated and not treated control (Table 3 ).

Table 2. Mycelial growth, sporulation and conidial germination of Aspergillus sp. in potato-dextrose-agar culture medium with different concentrations of essential oils of Citrus latifolia and Cinnamomum zeylanicum.

\begin{tabular}{|c|c|c|c|}
\hline b 1 & $\begin{array}{l}\text { mycelial }(\mathrm{cm}) \\
\text { Growth }^{1}\end{array}$ & $\begin{array}{l}\text { Sporulation }{ }^{2} \text { (number } \\
\text { of conidia/colony } 10^{7} \text { )* }\end{array}$ & Germination $^{3}(\%)^{*}$ \\
\hline Control & $7.20 \mathrm{f}$ & $2.50 \mathrm{~cd}$ & $90.00 \mathrm{c}$ \\
\hline Fungicide & $2.12 b$ & $0.64 b$ & $3.33 a$ \\
\hline EO C. Iatifolia $0,1 \%$ & 6.78 ef & $2.50 \mathrm{~cd}$ & $69.50 \mathrm{bc}$ \\
\hline EO C. Iatifolia $0,2 \%$ & 6.48 e & $2.81 \mathrm{~d}$ & $62.00 \mathrm{bc}$ \\
\hline EO C. Iatifolia $0,4 \%$ & $5.37 \mathrm{~d}$ & $2.39 \mathrm{~cd}$ & $49.50 \mathrm{bc}$ \\
\hline EO C. latifolia $0,8 \%$ & $4.70 \mathrm{c}$ & $1.01 \mathrm{bc}$ & $45.00 \mathrm{~b}$ \\
\hline EO C. zeylanicum $0,1 \%$ & $0.00 \mathrm{a}$ & $0.00 \mathrm{a}$ & $12.50 \mathrm{a}$ \\
\hline EO C. zeylanicum 0,2\% & $0.00 \mathrm{a}$ & $0.00 \mathrm{a}$ & $0.00 \mathrm{a}$ \\
\hline EO C. zeylanicum 0,4\% & $0.00 \mathrm{a}$ & $0.00 \mathrm{a}$ & $0.00 \mathrm{a}$ \\
\hline EO C. zeylanicum 0,8\% & $0.00 \mathrm{a}$ & $0.00 \mathrm{a}$ & $1.00 \mathrm{a}$ \\
\hline
\end{tabular}

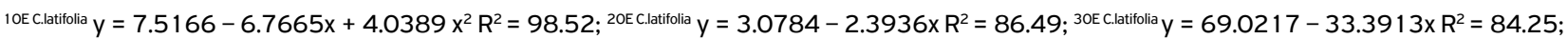
Fungicide: carbendazim $150 \mathrm{~g} \mathrm{~L}^{-1}+$ thiram $350 \mathrm{~g} \mathrm{~L}^{-1}$; means followed by the same letter in column do not differ statistically among themselves by Tukey test $(p<0.05)$; ${ }^{*}$ for the purpose of analysis, the data were transformed to square root of $Y+1.0$ - Sqrt $(Y+1.0)$; EO: essential oils. 
Both the seeds inoculated with Aspergillus sp. and Penicillium sp. presented higher germination percentages in relation to the increase of the concentration of the $\mathrm{EO}$ of $C$. latifolia, which highlights its potential fungicidal activity for both fungi. When the EO of C. zeylanicum was used, the bean seeds showed a reduction in the germination to the extent of increasing the oil concentration. Thus, in spite of being more efficient in the fungal inhibition (Tables 1 and 2) the EO of C. zeylanicum showed phytotoxic effect to the seeds (Table 3 ).

When the seeds inoculated with Penicillium sp. and Aspergillus sp. were compared, no difference was observed among the treatments, except for seeds treated with fungicide (positive control) and treated with C. zeylanicum $0.2 \%$ (Table 3 ), which showed lower germination of seeds inoculated with Aspergillus sp.

In the first count of germination and GSI (Tables 4 and 5) it was observed the same behavior of the germination test, in which both the seeds inoculated with Aspergillus sp. and the ones inoculated with Penicillium sp. presented a greater force in proportion to the increase in the concentration of the $\mathrm{EO}$ of $C$. latifolia. On the other hand, when the $\mathrm{EO}$ of $C$. zeylanicum was used, the bean seeds reduced the force to the extent of increasing the oil concentration, demonstrating once more, the fungicidal potential presented by the $\mathrm{EO}$ of $C$. latifolia, and the phytotoxic effect of $\mathrm{EO}$ of $C$. zeylanicum to the bean seeds. In a study on the allelopathic potential of the $\mathrm{EO}$ of medicinal plants on the germination of pepper seeds, MOURA et al. (2013) also observed lower germination capacity in seeds treated with EO of C. zeylanicum, which was capable of completely inhibiting the germination of the pepper seeds at a concentration of $1 \%$.

In general, when seeds inoculated with Penicillium sp. and Aspergillus sp. were compared, it was noted greater negative

Table 3. Germination of seeds inoculated with Aspergillus sp. and Penicillium sp. and treated with different concentrations of essential oils of Citrus latifolia and Cinnamomum zeylanicum.

\begin{tabular}{lcc} 
Treatments & Germination (\%) & Germination (\%) \\
\cline { 2 - 3 } & Aspergillus spp. & Penicillium spp. \\
\hline Control & $93.50 \mathrm{Aa}$ & $93.50 \mathrm{Aa}$ \\
\hline Negative Control & $62.50 \mathrm{Acd}$ & $52.00 \mathrm{Acd}$ \\
\hline Positive control & $31.50 \mathrm{Ae}$ & $13.50 \mathrm{Bf}$ \\
\hline EO C. latifolia 0,4\% & $52.00 \mathrm{Ad}$ & $60.00 \mathrm{Abc}$ \\
\hline EO C. latifolia 0,8\% & $77.50 \mathrm{Ab}$ & $69.50 \mathrm{Ab}$ \\
\hline EO C. zeylanicum 0,1\% & $77.00 \mathrm{Abc}$ & $68.00 \mathrm{Ab}$ \\
\hline EO C. zeylanicum 0,2\% & $54.75 \mathrm{Ad}$ & $39.25 \mathrm{Bde}$ \\
\hline EO C. zeylanicum 0,4\% & $33.00 \mathrm{Ae}$ & $24.75 \mathrm{Aef}$ \\
\hline EO C. zeylanicum 0.8\% & $12.50 \mathrm{Af}$ & $10.00 \mathrm{Af}$ \\
\hline
\end{tabular}

Control non-inoculated and not treated seeds; negative control: inoculated and not treated seeds; positive control: seeds treated with the fungicide carbendazim $150 \mathrm{~g} \mathrm{~L}^{-1}+$ thiram $350 \mathrm{~g} \mathrm{~L}^{-1}$; means followed by the same uppercase letter in the lines do not differ statistically among themselves by Tukey test $(p<0.05)$; EO: essential oils. effect on the vigor of the seeds inoculated with Penicillium sp. (Tables 4 and 5). Penicillium sp. is one of the main fungi responsible for the deterioration of stored seeds, being capable of reaching the tissues and cause a reduction in the force of the seeds and on their physiological quality (SOUZA et al., 2017). When the chemical treatment of the seeds was performed, there was a reduction in the germination, first count of germination and GSI in comparison to the negative control and the treatments with

Table 4. First count of germination of seeds inoculated with Aspergillus sp. and Penicillium sp. and treated with different concentrations of essential oils of Citrus latifolia and Cinnamomum zeylanicum.

\begin{tabular}{lcc} 
Treatments & $\begin{array}{c}\text { First count of } \\
\text { germination (\%) } \\
\text { Aspergillus spp. }\end{array}$ & $\begin{array}{c}\text { First count of } \\
\text { germination (\%) }\end{array}$ \\
\hline Conicillium spp. \\
\hline Negative Control & $31.50 \mathrm{Ab}$ & $31.50 \mathrm{Aab}$ \\
\hline Positive control & $24.50 \mathrm{Abc}$ & $6.00 \mathrm{Ac}$ \\
\hline EO C. latifolia $0,4 \%$ & $25.00 \mathrm{Acd}$ & $4.00 \mathrm{Ac}$ \\
\hline EO C. latifolia $0,8 \%$ & $60.50 \mathrm{Aa}$ & $17.50 \mathrm{Abc}$ \\
\hline EO C. zeylanicum $0,1 \%$ & $59.00 \mathrm{Aa}$ & $18.00 \mathrm{Bbc}$ \\
\hline EO C. zeylanicum $0,2 \%$ & $36.00 \mathrm{Ab}$ & $12.5 \mathrm{Bbc}$ \\
\hline EO C. zeylanicum $0,4 \%$ & $30.00 \mathrm{Ab}$ & $12.00 \mathrm{Bbc}$ \\
\hline EO C. zeylanicum $0.8 \%$ & $3.00 \mathrm{Ad}$ & $5.50 \mathrm{Ac}$ \\
\hline
\end{tabular}

Control non-inoculated and not treated seeds; negative control: inoculated and not treated seeds; positive control: seeds treated with the fungicide carbendazim $150 \mathrm{~g} \mathrm{~L}^{-1}+$ thiram $350 \mathrm{~g} \mathrm{~L}^{-1}$; means followed by the same uppercase letter in the lines do not differ statistically among themselves by Tukey test $(p<0.05)$; EO: essential oils.

Table 5. Germination speed index of seeds inoculated with Aspergillus sp. and Penicillium sp. and treated with different concentrations of essential oils of Citrus latifolia and Cinnamomum zeylanicum.

\begin{tabular}{lcc}
\multirow{2}{*}{ Treatments } & \multicolumn{1}{c}{ GSI } & \multicolumn{1}{c}{ GSI } \\
\cline { 2 - 3 } Negative Control & Aspergillus spp. & Penicillium spp. \\
\hline Positive control & $2.49 \mathrm{Ab}$ & $4.25 \mathrm{Abc}$ \\
\hline EO C. latifolia 0,4\% & $4.58 \mathrm{Abc}$ & $1.06 \mathrm{Be}$ \\
\hline EO C. latifolia $0,8 \%$ & $7.95 \mathrm{Aa}$ & $\mathbf{A a b}$ \\
\hline EO C. zeylanicum $0,1 \%$ & $8.15 \mathrm{Aa}$ & $5.91 \mathrm{Ba}$ \\
\hline EO C. zeylanicum $0,2 \%$ & $5.24 \mathrm{Ab}$ & $3.23 \mathrm{Bcd}$ \\
\hline EO C. zeylanicum $0,4 \%$ & $3.39 \mathrm{Acd}$ & $2.26 \mathrm{Bde}$ \\
\hline EO C. zeylanicum $0.8 \%$ & $0.94 \mathrm{Ae}$ & $0.89 \mathrm{Ae}$ \\
\hline
\end{tabular}

Negative control: seeds inoculated and not treated; positive control: seeds treated with the fungicide carbendazim $150 \mathrm{~g} \mathrm{~L}^{-1}+$ thiram $350 \mathrm{~g} \mathrm{~L}^{-1}$; means followed by the same uppercase letter in the lines and the same lowercase letter in the columns do not differ statistically among themselves by Tukey test ( $p<0.05)$; GSI: germination speed index; EO: essential oils. 
EOs (Tables 3, 4 and 5). These results indicate that the fungicide causes higher phytotoxicity to bean seeds among the evaluated treatments. As CONCEIÇÃO (2013) points out, when some chemicals are used directly in seeds, a decrease in germination and survival of seedlings may be caused by phytotoxicity problems. The level of phytotoxicity will depend on the cultivar used, plant protection product, applied dose and the stage of development in which the product was applied (TAKANO et al., 2015).

Regarding the results obtained in the seed health test, it was observed that, for the bean seeds inoculated with the fungus Aspergillus sp. (Table 6) there was no significant action of the EO of $C$. latifolia in control of the genus of the mentioned fungus, whereas the $\mathrm{EO}$ of $C$. zeylanicum promoted increasing reductions in the incidence of the fungus Aspergillus spp. with the increase in its concentration. For the fungus Penicillium spp., the $\mathrm{EO}$ of $C$. zeylanicum promoted total inhibition on incidence of the fungus.

The decrease in fungal development starting from the increase in the concentration of EOs was also verified by AQUINO et al.
(2014), who observed a reduction in the germination of conidia of the fungus Colletotrichum gloeosporioides with increasing concentration of pepper-rosmarin, lemon grass and basil-harpsichord.

Still on the sanity test, in the case of the fungus Cladosporium spp., its incidence also decreased with the increase in concentrations of EOs of C. latifolia and C. zeylanicum, whereas the occurrence of fungus Rhizopus spp. influenced by the different treatments did not happen. This last result may indicate greater resistance of the genus Rhizopus to alternative seeds treatment with EOs, being necessary the study of other control methods for this genre. Fusarium spp. and Chaetomium spp. had low occurrence in the seeds (Table 6).

For the seeds inoculated with the fungus Penicillium sp. (Table 7), there was no difference among the treatments for the incidence of the genus Aspergillus. Regarding the occurrence of the fungus Penicillium spp., the EO of C. zeylanicum reduced the incidence regardless of the concentration used and also the $\mathrm{EO}$ of $C$. latifolia in $0.4 \%$ concentration. The fungus Rhizopus spp. was totally controlled by the EO of

Table 6. The presence of the fungi Aspergillus spp. (Asp.), Penicillium spp. (Pen), Cladosporium spp. (CLA), Fusarium spp. (FUS), Chaetomium spp. (CHA) and Rhizopus spp. (Rhi) in seeds inoculated with the fungus Aspergillus sp. and treated with different concentrations of essential oils of Citrus latifolia and Cinnamomum zeylanicum.

\begin{tabular}{lcccccc|}
\hline Treatments & Asp. (\%) & Pen. (\%) & Cla. (\%) & Fus. (\%) & Cha. (\%) & Rhi. (\%) \\
\hline Negative Control & $23.00 \mathrm{bc}$ & $13.00 \mathrm{bc}$ & $3.00 \mathrm{ab}$ & $2.00 \mathrm{a}$ & $0.00 \mathrm{a}$ & $65.25 \mathrm{a}$ \\
\hline Positive control & $18.00 \mathrm{~b}$ & $2.00 \mathrm{abc}$ & $0.00 \mathrm{a}$ & $0.00 \mathrm{a}$ & $0.00 \mathrm{a}$ & $96.00 \mathrm{a}$ \\
\hline EO C. latifolia $0,4 \%$ & $15.00 \mathrm{~b}$ & $10.00 \mathrm{abc}$ & $6.00 \mathrm{~b}$ & $4.00 \mathrm{a}$ & $1.00 \mathrm{a}$ & $34.00 \mathrm{a}$ \\
\hline EO C. latifolia $0,8 \%$ & $14.00 \mathrm{~b}$ & $2.00 \mathrm{ab}$ & $1.00 \mathrm{a}$ & $0.00 \mathrm{a}$ & $0.00 \mathrm{a}$ & $100.00 \mathrm{a}$ \\
\hline EO C. zeylanicum $0,1 \%$ & $38.75 \mathrm{c}$ & $10.00 \mathrm{abc}$ & $1.00 \mathrm{a}$ & $0.00 \mathrm{a}$ & $0.00 \mathrm{a}$ & $37.00 \mathrm{a}$ \\
\hline EO C. zeylanicum 0,2\% & $23.00 \mathrm{bc}$ & $20.00 \mathrm{c}$ & $1.00 \mathrm{a}$ & $0.00 \mathrm{a}$ & $0.00 \mathrm{a}$ & $36.00 \mathrm{a}$ \\
\hline EO C. zeylanicum 0,4\% & $14.75 \mathrm{~b}$ & $1.00 \mathrm{ab}$ & $0.00 \mathrm{a}$ & $0.00 \mathrm{a}$ & $6.00 \mathrm{a}$ & $42.00 \mathrm{a}$ \\
\hline EO C. zeylanicum 0,8\% & $2.00 \mathrm{a}$ & $0.00 \mathrm{a}$ & $0.00 \mathrm{a}$ & $0.00 \mathrm{a}$ & $1.00 \mathrm{a}$ & $65.00 \mathrm{a}$
\end{tabular}

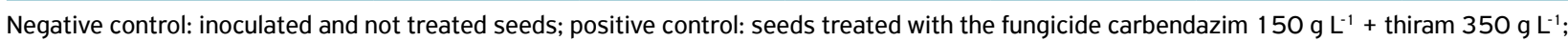
means followed by the same letter in column do not differ statistically among themselves by Tukey test $(p<0.05)$; * for the purpose of analysis, the data were transformed to square root of $Y+1.0$ - SQRT $(Y+1.0)$; EO: essential oils.

Table 7. The presence of the fungi Aspergillus spp. (Asp.), Penicillium spp. (Pen), Cladosporium spp. (CLA), Fusarium spp. (FUS), Chaetomium spp. (CHA) and Rhizopus spp. (Rhi) in seeds inoculated with the fungus Penicillium sp. and treated with different concentrations of essential oils of Citrus latifolia and Cinnamomum zeylanicum.

\begin{tabular}{lcccccc} 
Treatments & Asp. (\%) & Pen. (\%) & Cla. (\%) & Fus. (\%) & Cha. (\%) & Rhi. (\%) \\
\hline Negative control & $11.00 \mathrm{a}$ & $61.25 \mathrm{c}$ & $4.00 \mathrm{a}$ & $0.00 \mathrm{a}$ & $0.00 \mathrm{a}$ & $18.00 \mathrm{ab}$ \\
\hline Positive control & $3.00 \mathrm{a}$ & $18.00 \mathrm{~b}$ & $8.00 \mathrm{a}$ & $0.00 \mathrm{a}$ & $0.00 \mathrm{a}$ & $12.00 \mathrm{ab}$ \\
\hline EO C. latifolia $0,4 \%$ & $2.00 \mathrm{a}$ & $28.00 \mathrm{~b}$ & $0.00 \mathrm{a}$ & $0.00 \mathrm{a}$ & $0.00 \mathrm{a}$ & $25.00 \mathrm{ab}$ \\
\hline EO C. latifolia $0,8 \%$ & $3.00 \mathrm{a}$ & $65.00 \mathrm{c}$ & $2.00 \mathrm{a}$ & $0.00 \mathrm{a}$ & $0.00 \mathrm{a}$ & $54.75 \mathrm{ab}$ \\
\hline EO C. zeylanicum $0,1 \%$ & $6.00 \mathrm{a}$ & $1.00 \mathrm{a}$ & $2.00 \mathrm{a}$ & $0.00 \mathrm{a}$ & $0.00 \mathrm{a}$ & $88.00 \mathrm{~b}$ \\
\hline EO C. zeylanicum $0,2 \%$ & $7.00 \mathrm{a}$ & $2.00 \mathrm{a}$ & $0.00 \mathrm{a}$ & $0.00 \mathrm{a}$ & $2.00 \mathrm{a}$ & $39.00 \mathrm{ab}$ \\
\hline EO C. zeylanicum $0.4 \%$ & $3.00 \mathrm{a}$ & $0.00 \mathrm{a}$ & $0.00 \mathrm{a}$ & $0.00 \mathrm{a}$ & $0.00 \mathrm{a}$ & $23.00 \mathrm{ab}$ \\
\hline EO C. zeylanicum $0,8 \%$ & $1.00 \mathrm{a}$ & $0.00 \mathrm{a}$ & $0.00 \mathrm{a}$ & $0.00 \mathrm{a}$ & $0.00 \mathrm{a}$ & $0.00 \mathrm{a}$ \\
\hline
\end{tabular}

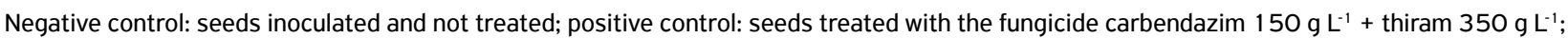
Asp.: Aspergillus spp.; Pen: Penicillium spp.; CLA: Cladosporium spp.; FUS: Fusarium spp.; CHA: Chaetomium spp.; Rhi: Rhizopus spp.; means followed by the same letter in column do not differ statistically among themselves by Tukey test $(p<0.05)$; *for the purpose of analysis, the data were transformed to square root of $Y+1.0-\mathrm{SQRT}(\mathrm{Y}+1.0)$; EO: essential oils. 
C. zeylanicum in $0.8 \%$ concentration. The fungi, Cladosporium spp., Fusarium spp. and Chaetomium spp. had low incidence.

By the results presented in Tables 6 and 7, it is observed that the control exercised by the EOs, on the different genera of fungi in bean seeds, was similar to the results obtained with conventional treatment using a fungicide, which proves the efficiency of waste oils as an alternative in the pathogenic fungi control. It is also observed that the genera of fungi of greater occurrence in bean seeds were Aspergillus, Penicillium and Rhizopus. The results show the potential of these EOs in the treatment of common bean seeds and the importance of advancing in studies to facilitate the practical use in the field.

\section{CONCLUSIONS}

The EO of Cinnamomum zeylanicum was more efficient in the control of the fungi Aspergillus sp. and Penicillium sp., but affects the physiological quality of the beans seeds as the fungicide.

The EO of Citrus latifolia was less efficient in the control of the fungi Aspergillus sp. and Penicillium sp., however it affects in lower degree the physiological quality of the bean seeds.

The fungal diversity identified in seed health testing is composed by Aspergillus spp., Penicillium spp., Cladosporium spp., Fusarium spp., Chaetomium spp. and Rhizopus spp., with greater frequency for Aspergillus spp., Penicillium spp. and Rhizopus spp.

\section{ACKNOWLEDGMENTS}

The authors are thankful to Universidade Federal da Fronteira Sul, Campus Laranjeiras do Sul, Paraná for support and encouragement to post-graduation strictu sensu of UFFS, by Grant Notice No 1010/GR/UFFS/2018.

| | | | | | | | | | | | | | | | | | | | | | | | | | | | | | | | | | | | | | | | | | | | | | | | | | | | | | | | | | | | | | | | | | | | | | | | | | | | | | | | | | | | | | | | | | | | | | | | | | | | | | | | | | | | | | | | | | | | | | | | | | | | | | | | | | | | | | | | | | | | | | | | | | | | | | | | | | | | | | | | | | | | | | | | | | | | | | | | | | | | | | | | | | | | | | | | | | | | | | | | | | | | | | | | | | REFERENCES

AL-BAYATI, F.A.; MOHAMMED, M.J. Isolation, identification, and purification of cinnamaldehyde from Cinnamomum zeylanicum bark oil. An antibacterial study. Pharmaceutical Biology, v.47, n.1, p.61-66, 2009. https://doi. org/10.1080/13880200802430607

AQUINO, C.F.; SALES, N.L.P.; SOARES, E.P.S.; MARTINS, E.R.; COSTA, C.A. Chemical composition and in vitro activity of three essential oils on passion fruit Colletotrichum gloeosporioides. Revista Brasileira de Plantas Medicinais, v.16, n.2, p.329-336, 2014. http://dx.doi.org/10.1590/1983-084X/12_115

BITU, P.I.M.; SANTOS, L.V.S. dos; RODRIGUES, A.A.C.; BRAUN, H.; MONTEIRO, O. dos S.; FERRAZ JUNIOR, A. S.de L.; SILVA, M.R.M. Alternative control of Corynespora cassiicola in papaya seedling and fruits by Cinnamomum zeylanicum essential oil. African Journal of Agricultural Research, v.11, n.20, p.18621871, 2016. https://doi.org/10.5897/AJAR2015.10754

BRASIL. Ministry of Agriculture, Livestock and Food Supply. Rules for seed analysis. Brasília: Secretaria de Defesa Agropecuária, 2009.

CHAGAS, H.A.; BASSETO, M.A.; ROSA, D.D.; TOPPA, E.V.B. FURTADO, E.L.; ZANOTTO, M.D. Evaluation of fungicides, essential oils and biological agents in the control of Amphobotrys ricini in castor bean (Ricinus communis L.). Summa Phytopathologica, v.40, n.1, p.42-48, 2014. http://dx.doi.org/10.1590/ SO $100-54052014000100006$

CONCEIÇÃO, G.M. Chemical treatment of soybean seeds: physiological, sanitary quality and storage potential. Dissertation (master's degree) - Universidade Federal de Santa Maria, Santa Maria, 2013.
CUNHA, R.P.; CORREAA, M.F.; SCHUCH, L.O.B.; OLIVEIRA, R.C.; ABREU JUNIOR, J.S.; SILVA, J.D.G.; ALMEIDA, T.L. Different treatments of seeds on the development of soybean plants. Ciência Rural, v.45, n.10, p.1761-1767, 2015. http://dx.doi. org/10.1590/0103-8478cr20140742

DALLA PRIA, M.; SILVA, O.C. Anthracnose. In: DALLA PRIA, M.; SILVA, O.C. Bean culture: diseases and control. 2. ed. Ponta Grossa: Editora UEPG, 2010. p.49-56.

FRENCH, R.C.; LONG, R.K.; LATTERELL, F.M.; GRAHAM, C.L.; SMOOT J.J.; SHAW, P.E. Effect of Nonanal, Citral, and citrus oils on germination of conidia of Penicillium digitatum and Penicillium italicum. Phytopathology, Lancaster, v.68, n. 1, p.877-882, 1978.

GHINI, R.; KIMATI, H. Resistance of fungi to fungicides. 1. ed. Jaguariúna: Embrapa Meio Ambiente, 2000. 78p.

GOMES, R.S.S.; NUNES, M.C.; SOUZA, J.O.; PORCINO, M.M. Efficiency of essential oils in the sanitary and physiological quality of lima bean seeds (Phaseolus lunatus L.). Revista Brasileira de Plantas Medicinais, v.18, suppl.1, p.279-287, 2016. http://dx.doi. org/10.1590/1983-084X/15_117

KRISCH, J.; TSERENNADMID, R.; VAGVÖLGYI, C. Essential oils against yeasts and moulds spoilage. In: MENDEZ-VILAS, A. (Ed.). Science against microbial pathogens: communicating current research and technological advances. Formatex Research Center, v.2, n. 1, p.1 135-1 142, 2011.

MAGUIRE, J.D. Speed of germination aid in selection and evaluation for seedling emergence and vigor. Crop Science, Madison, v.2, n.2, p.176-77, 1962. http://dx.doi.org/10.2135/ cropsci $1962.0011183 \times 000200020033 x$ 
MARINO, R.H.; MESQUITA, J.B. Micoflora of common bean (Phaseolus vulgarius L.) seeds from Sergipe state. Revista Brasileira de Ciências Agrárias, v.4, n.3, p.252-256, 2009.

MARJANLO, A.A.; MOSTOFI, Y.; SHOEIBI, S.H.; FATTAHI, M. Effect of cumin essential oil on postharvest decay and some quality factors of strawberry. Journal of Medicinal Plants, v.8, n.31, p.25-43, 2009.

MENTEN, J.O.M. Loss caused by pathogens associated with seeds. In: MENTEN, J.O.M. Seed pathogens: detection, damage and chemical control. Piracicaba: ESALQ/FEALQ, 1995. p.115-136.

MOURA, G.S.; JARDINETTI, V.A.; NOCCHI, P.T.R.; SCHWANESTRADA, K.R.F.; FRANZENER, G. Allelopathic potential of the essential oil of medicinal plants on the germination and initial development of Bidens pilosa and Capsicum annuum. Ensaios e Ciência: Ciências Biológicas, Agrárias e da Saúde, v.17, n.2, p.51-62, 2013.

OOTANI, M.A.; AGUIAR, R.W.; RAMOS, A.C.C.; BRITO, D.R.; SILVA, J.B.; CAJAZEIRA, J.P. Use of essential oils in agriculture. Journal of Biotechnology and Biodiversity, v.4, n.2, p.162-174, 2013.

OOTANI, M.A.; BRITO, D.R.; MACIEL, G.P.S.; LOPES, L.A.; AGUIAR, R.W.S. Effect of essential oils and citronellal compound on bean seeds stored microflora. Revista Verde de Agroecologia e Desenvolvimento Sustentável, v.1 1, n. 1, p.49-56, 2016. http:// dx.doi.org/10.18378/rvads.v1 1i 1.3836

SILVA, R.A.C.; SOUZA, T.O.; DIAS, L.P.; ANDRADE, T.J.A.S. Action of the methanolic extract of Moringa oleifera on the mycelial growth of plant pathogens. In: CONGRESSO DE PESQUISA E INOVAÇÃO DA REDE NORTE E NORDESTE DE INOVAÇÃO TECNOLÓGICA, 4.. Belém, PA, 2009.

SILVA, J.F.; MELO, B.A.; PESSOA, E.B.; FIGUEIREDO NETO, A.; LEITE, D.T. Plant extracts for the control the bean weevil Zabrotes subfaciatus (Boheman 1833) (Coleoptera: Bruchidae). Revista Verde de Agroecologia e Desenvolvimento Sustentável, v.8, n.3, p.01-05, 2013.

SILVA, M.M.; SOUZA, H.R.T.S; DAVID, A.M.S.S.; SANTOS, L.M.; SILVA, R.F.; AMARO, H.T.R. Physiological quality and seed storage of common bean grown in the north of Minas Gerais. Revista Agro@mbiente Online, v.8, n.1, p.97-103, 2014.

SIVAKUMAR, D.; BAUTISTA-BAÑOS, S. A review on the use of essential oils for postharvest decay control and maintenance of fruit quality during storage. Crop Protection, v.64, p.27-37, 2014. http://dx.doi.org/10.1016/j.cropro.2014.05.012

SOUZA, E.P.; PERINO, F.H.B.; MOSCATO, B.S.; FREITAS, P.G.N.; BLUMER, S.; CARDOSO, A.II.I; BONINI, C.S.B.; BONINI NETO, A. Extract of propolis in control of Penicillium sp. and in the quality of cauliflower seeds. Brazilian Journal of Biosystems Engineering, v. 1 1, n.2, p.135-141, 2017. http://dx.doi.org/10.18011/bioeng2017v11n2p135-141

STONE, L. F.; FERREIRA, E. P. de B.; DIDONET, A. D.; HEINEMANN, A. B.; OLIVEIRA, J. P. de. Correlation between common bean yield under organic production and soil attributes. Revista Brasileira de Engenharia Agrícola e Ambiental, v.17, n. 1, p.19-25, 2013. http://dx.doi.org/10.1590/S1415-43662013000100003

TAKANO, H.K.; BRAZ, G.B.P.; JUNIOR, R.S.O.; CONSTANTIN, J.; RIOS, F.A.; GHENO, E.A.; BIFFE, D.F.; FRANCHINI, L.H.M. Reduction of phytotoxicity by herbicides applied in common beans with the use of fungicides. Revista Agrarian, v.8, n.27, p.12-22, 2015.

TOLEDO, M.Z.; FONSECA, N.R.; CÉSAR, M.L.; SORATTO, R.P.; CAVARIANI, C.; CRUSCIOL, C.A.C. Physiological quality and storage of bean seeds as affected by late side dressing nitrogen. Pesquisa Agropecuária Tropical, v.39, n.2, p.124-133, 2009.

VANZOLINI, S.; TORRES, R.M.; PANIZZI, R.C. Effects of size, density and fungicidal treatment on peanut seed quality. Revista Ceres, v.47, n.274, p.603-612, 2000.

VIEGAS, E.C.; SOARES, A.; CARMO, M.G.F.; ROSSETO, C.A.V. Evaluation of essential oils from Allium sativum and Cinnamomum zeilanicum and their toxicity against fungi of the Aspergillus flavus group. Horticultura Brasileira, v.23, n.4, p.915-919, $2005 a$. http://dx.doi.org/10.1590/SO102-05362005000400010

VIEGAS, E.C.; NASCIMENTO, F.G.; MEYRELLES, B.G.; ROSSETTO, C.A.V. Physiological quality of stored peanut seeds influenced by synthetic and vegetable products. Revista Brasileira de Plantas Medicinais, v.7, n.3, p.79-85, 2005b. 